\title{
Using Distributed Energy Resources
}

\author{
A How-To Guide for Federal Facility Managers
}

\section{Introduction}

As one of today's busy Federal facility or energy managers, you may be seeking ways to solve problems such as high energy costs or low electric power reliability at your facility. If so, distributed energy resources (DER) could be the solution you're looking for.

\section{What are distributed energy resources?}

Distributed energy resources are small, modular, energy generation and storage technologies that provide electric capacity or energy where you need it. Typically producing less than 10 megawatts (MW) of power, DER systems can usually be sized to meet your particular needs and installed on site.

DER systems may be either connected to the local electric power grid or isolated from the grid in stand-alone applications. DER technologies include wind turbines, photovoltaics
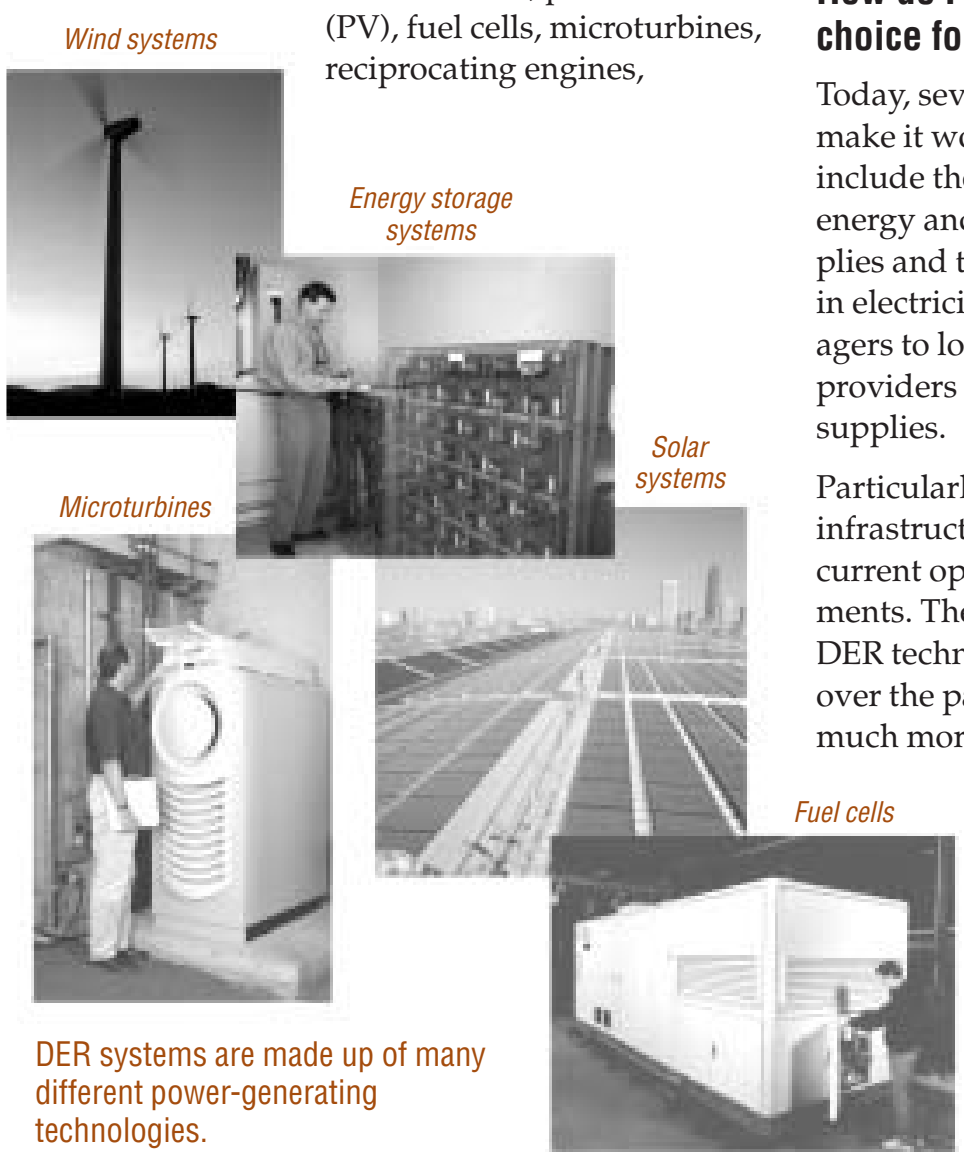

technologies combustion turbines, cogeneration, and energy storage systems.

\section{How are DER systems used?}

DER systems can be used in several ways. They can help you manage energy bills and ensure reliable power by augmenting your current energy services. DER systems also enable a facility to operate independently of the electric power grid, whether by choice or out of necessity. Certain DER systems can even lower emissions and improve fuel utilization on site.

Utilities can use DER technologies to delay, reduce, or even eliminate the need to obtain additional power generation, transmission, and distribution equipment and infrastructure. At the same time, DER systems can provide voltage support and enhance local reliability.

\section{How do I know if DER systems are the right choice for my facility?}

Today, several economic and environmental factors make it worthwhile to consider DER. These factors include the high prices associated with both electric energy and fuel in recent years. Uncertain fuel supplies and the increasing potential for disruptions in electricity service are prompting Federal managers to look for alternatives to traditional energy providers and for new ways to supplement current supplies.

Particularly where a facility's energy-producing infrastructure is aging, it may be time to review current operating costs and maintenance requirements. The performance, cost, and availability of DER technologies have all been improving steadily over the past several years. New technologies are much more efficient than old ones, so a replacement or upgrade may pay for itself sooner than expected. Also, energy security is a primary concern at many Federal facilities. In those cases, DER systems can power mission-critical loads, reduce hazardous or costly power outages, and diversify the local energy supply.

Military facility energy managers, however, may want to consider the likelihood of privatization in deciding
Distributed Energy Resources: A How-To Guide
U.S. Department

of Energy

Office of Energy

Efficiency and

Renewable Energy 
whether to invest in a DER system. If the facility's utility infrastructure could soon be sold to a private entity, it might not make economic sense to invest in a new DER system that would be unacceptable to a potential buyer. But in the right circumstances, even military facilities can benefit from using DER.

\section{What is the purpose of this guide?}

The Department of Energy's (DOE's) Federal Energy Management Program (FEMP) has established the Distributed Energy Resources Program to assist Federal agencies in implementing DER projects at their facilities. FEMP prepared this How-To Guide to assist facility managers in evaluating potential applications and benefits. The guide also provides practical, step-by-step advice on how to carry out a Federal DER project. It describes and explains-

- DER applications, and the potential benefits of using DER in Federal facilities

- DER technologies, and how to match them to applications

- A step-by-step approach to implementing projects

- Barriers that you may encounter, and how to overcome them

- Resources that can assist you in implementing new DER projects.

We hope this guide helps to make your DER projects a success.

\section{Seven Steps to Success}

How do you, as an energy or facility manager, determine whether DER will make sense for your facility's energy needs? And if so, which technology or system is the best? Finally, what is the process you need to follow to get a DER project financed, designed, installed, and operating?

Before even considering DER, make sure you have taken advantage of all the energy-saving measures that are available and applicable to your facility. These include using highly efficient insulation, lighting, and heating, ventilation, and air-conditioning (HVAC), as well as passive solar design and other effective techniques. (See FEMP's Web site, www.eren.doe.gov/femp/, for more information about energy-efficient facilities.) The more you can reduce your energy requirements, the smaller you can size the DER system you will be installing. Here are seven steps you can follow to obtain a DER system that's right for you.

\section{STEP 1: Analyze Your Facility's Energy Needs}

In this step, you can determine what your facility's energy needs are, what problems you need to solve, and what benefits can be gained by using DER systems. This list of basic DER applications will help you determine which one or ones apply to your facility. It will also help you choose appropriate DER technologies in Step Two.

- Standby Power. Problem: Your power supplier has an unacceptably high incidence of service interruptions, or takes a long time to restore service after an interruption. This is called low reliability, and the result is a shutdown in operations until power is restored. Solution: Install a DER system that can meet your power needs when service is interrupted, to serve critical loads until service is restored. Benefits: Highly reliable operation, minimal down time.

- Low-Cost Energy. Problem: Your energy supplier has high rates. Solution: Install a DER system to generate some or all of your facility's power using renewable technologies, or change to more efficient and cleaner sources of fossil fuel generation. Benefit: Lower energy bills.

- Stand-Alone Systems. Problem: Your facility needs electric energy, but it is in a location that can't be served economically by traditional utilities. Solution: Install a DER system to generate power dedicated solely to offgrid loads. Benefits: Independent operation, cost savings.

- Combined Heat and Power (CHP, or Cogeneration). Problem: Your facility

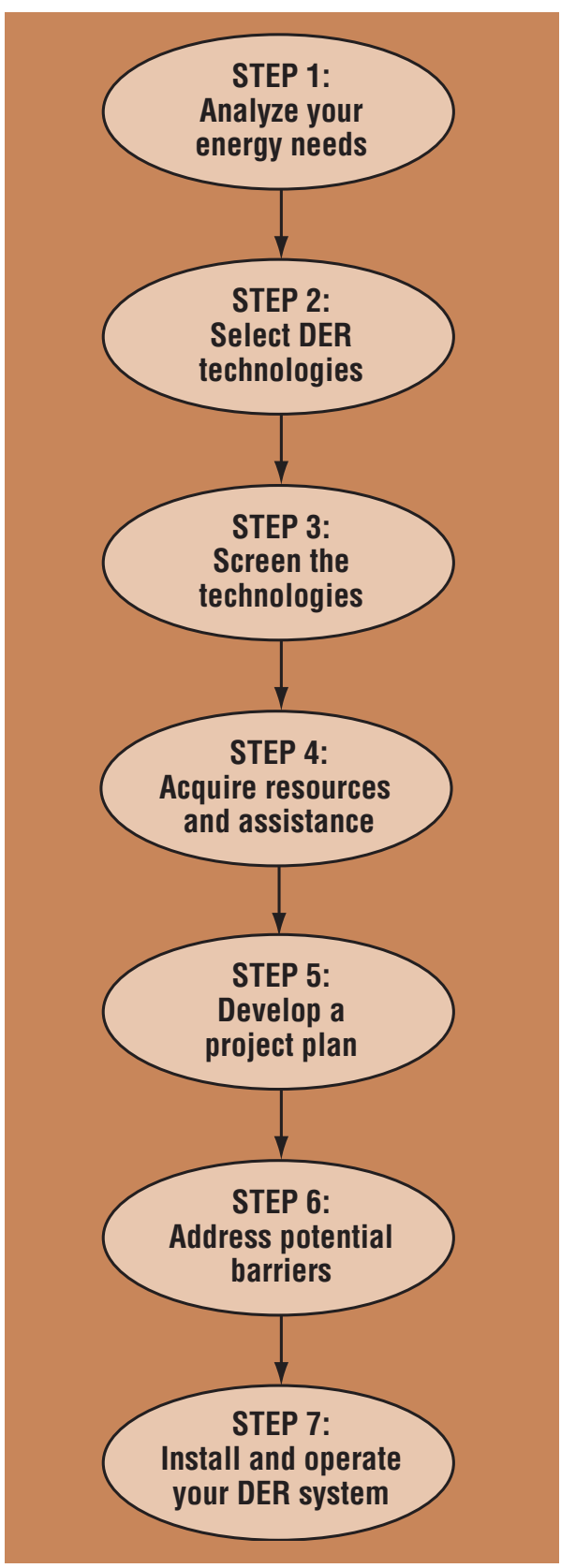

Following these seven steps will help you implement a successful DER project.

needs electric energy, but it also has other energy needs, for example, to heat or cool water or interior spaces. Solution: Install a DER system to generate power and use the waste heat for auxiliary processes that would otherwise require fuel. Benefits: Substantially greater efficiency, lower energy costs and fuel requirements, and fewer air emissions, in many cases. (See p. 6, Table 2, for more information.) 
- Peak Shaving. Problem: Your power supplier bills you a monthly charge based on your highest peak usage rate, even if it's only a few hours each month. Solution: Install a DER to provide power during times of peak usage to lower demand charges. Benefit: Lower monthly utility bills.

- Improved Power Quality (PQ). Problem: The power provided to your facility by your energy supplier is not electrically "clean" or constant, causing problems with your facility's equipment (see page 8 for details). Solution: Install a DER system designed to mitigate the particular power quality symptoms you are experiencing. For example, frequent momentary outages can be effectively addressed with an uninterruptible power supply (UPS) system or a distributed storage device. Benefits: Obtain cleaner power, ride through momentary outages, protect delicate equipment.

- “Green" Power. Problem: Your facility is in an environmentally sensitive area. Solution: Install low- or zeroemission DER systems that generate environmentally preferable power, such as wind turbines, photovoltaics, fuel cells, or CHP systems. Replacing old power generation equipment with cleaner, more efficient DER technologies may also reduce emissions. Benefits: Easier emissions permitting, minimal environmental impacts.

\section{STEP 2: Select a DER Technology}

In this step, you can evaluate today's DER technologies, selecting the ones that meet your needs. Table 1 on pp. 4 and 5 shows which technologies are suitable for various DER applications. Refer to the table as you weigh the pros and cons of the candidate technologies.

DER systems can be made up of one or more primary technologies-such as internal combustion engines, combustion turbines, fuel cells, photovoltaics, wind turbines, and batteries-along with supporting technologies-such as power conditioning equipment, controls, communications, fuel handling and storage systems, CHP systems, and emission controls. You will also want to weigh important environmental and fuel-use issues.

\section{What are the technologies?}

Many combinations of technologies and fuel options are possible, to take advantage of the way individual technologies complement each other and to make them as robust and cost-effective as possible. See Table 2 for comparative cost and performance information about today's DER technologies, which include the following:

- Diesel Engine generator sets (gensets) consist of a diesel-cycle (compression ignition) reciprocating engine prime mover coupled to an electric generator. The diesel engine operates at a relatively high compression ratio and relatively low rpm. Diesel engine gensets are a proven, cost-effective, extremely reliable and widely used technology. They are manufactured in a wide range of sizes, from about 1 kilowatt $(\mathrm{kW})$ up to about $10 \mathrm{MW}$. They can be cycled frequently to operate as peak-load power plants or as load-following plants; they can also be run in baseload mode in off-grid systems. Major drawbacks include very high levels of emissions (particularly nitrogen oxides, a major component of smog), and the need for sound attenuation to muffle the loud engine noise. Diesel engines are thus probably not suitable for most Federal facilities, and should be considered only if other technologies are not practical. One of the least expensive DER technologies, they cost about $\$ 810 / \mathrm{kW}$, installed.

- Dual-Fuel Engine gensets consist of a diesel-cycle engine modified to use a mixture of natural gas and diesel fuel (typically, $5 \%$ to $10 \%$ diesel by volume) connected to an electric generator. The small amount of diesel fuel allows the use of compression ignition, and the high percentage of natural gas in the mix results in much

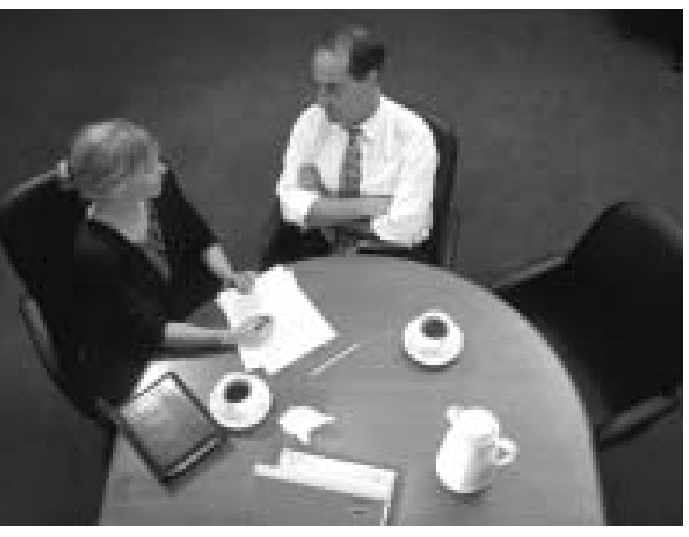

Selecting a technology requires a thorough analysis of your facility's energy needs.

lower emissions (and somewhat lower power output) than those of a diesel engine. In most other cost and operational respects, dual-fuel engines are comparable to diesels; they are available in sizes from a few kilowatts to about $10 \mathrm{MW}$ at an installed cost of about $\$ 875 / \mathrm{kW}$.

- Natural Gas Engine gensets are made up of a reciprocating (piston-driven) natural gas-fueled engine using a spark-ignition system (Otto fuel cycle) coupled to an electric generator. In most other respects, natural gas engines perform similarly to diesels and dual-fuel engines, but have the potential for the lowest emissions of all types of reciprocating engines. They are available in sizes from a few kilowatts to about $5 \mathrm{MW}$, and they cost about the same as diesel and dual-fuel engines-around $\$ 825 / \mathrm{kW}$.

- Combustion Turbines (also called gas turbines) burn gas or liquid fuel; hot gases expand against the blades of a rotating shaft, producing a high-speed rotary motion that drives an electric generator. While they may take a few more minutes to get up to speed in comparison to reciprocating engines, gas turbines are well suited for peaking and load-following applications and for baseload operation in larger sizes. Installed costs are somewhat higher than those of reciprocating engines, and maintenance costs are slightly lower. Turbines are efficient and relatively clean. They can 


\section{Matching DER Technologies to Your Applications}

When using this chart to select a technology for a specific application, you will also want to consider such key factors as commercial readiness, economics, availability, and environmental considerations before making your selection. The discussion that follows should provide some additional guidance in selecting the technologies.

\section{Table 1. DER Technology Applications Matrix}

\begin{tabular}{|c|c|c|c|c|c|c|c|}
\hline \multirow{2}{*}{\multicolumn{2}{|c|}{ Technology }} & \multicolumn{6}{|c|}{ Application } \\
\hline & & $\begin{array}{l}\text { Standby } \\
\text { Power }\end{array}$ & $\begin{array}{l}\text { Low-cost } \\
\text { Energy }\end{array}$ & $\begin{array}{l}\text { Stand- } \\
\text { alone } \\
\text { System }\end{array}$ & $\begin{array}{c}\text { Combined } \\
\text { Heat \& } \\
\text { Power }\end{array}$ & $\begin{array}{l}\text { Peak } \\
\text { Shaving }\end{array}$ & $\begin{array}{l}\text { Power } \\
\text { Quality }\end{array}$ \\
\hline \multirow{8}{*}{ 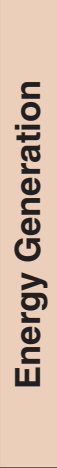 } & Diesel Engine & $\checkmark$ & $\checkmark$ & $\checkmark$ & $\checkmark$ & $\checkmark$ & \\
\hline & Natural Gas Engine & $\checkmark$ & $\checkmark$ & $\checkmark$ & $\checkmark$ & $\checkmark$ & \\
\hline & Dual Fuel Engine & $\checkmark$ & $\checkmark$ & $\checkmark$ & $\checkmark$ & $\checkmark$ & \\
\hline & Microturbine & $\checkmark$ & & $\checkmark$ & $\checkmark$ & $\checkmark$ & \\
\hline & Combustion Turbine & $\checkmark$ & $\checkmark$ & $\checkmark$ & $\checkmark$ & $\checkmark$ & \\
\hline & Fuel Cell & & (1) & $\checkmark$ & $\checkmark$ & & \\
\hline & Photovoltaics & & $(1)$ & $\checkmark$ & & $\checkmark$ & \\
\hline & Wind Turbine & & (1) & $\checkmark$ & & & \\
\hline \multirow{5}{*}{$\begin{array}{l}\text { ㅁ } \\
\text { 히 } \\
\text { के } \\
\text { के } \\
\text { Шे }\end{array}$} & Uninterruptible Power Supply (UPS) & $\checkmark$ & & & & & $\checkmark$ \\
\hline & Battery System & $\checkmark$ & & & & & $\checkmark$ \\
\hline & Flywheel & $\checkmark$ & & & & & $\checkmark$ \\
\hline & $\begin{array}{l}\text { Superconducting Magnetic Energy } \\
\text { Storage (SMES) }\end{array}$ & & & & & & $\checkmark$ \\
\hline & Hybrid Systems (2) & $\checkmark$ & $\checkmark$ & $\checkmark$ & $\checkmark$ & $\checkmark$ & $\checkmark$ \\
\hline
\end{tabular}

(1) Although fuel cells, photovoltaics, and wind turbines may not offer the lowest cost power option, their low environmental impacts greatly enhance the value of the power they provide.

(2) Hybrid systems are any combination of the technologies listed above.

Standby Power. To acquire the most economical DER power-generating system to use when the utility supply is down, you should first estimate how often the DER will have to start up and how many hours per year it will have to operate. For standby power applications, fuel and maintenance costs will be low because outages usually occur only a few hours per year; consequently, capital costs should be low. Diesel engines are likely to be the least expensive option, but they can present environm ental challenges. Natural gas and dual-fuel engines may be more environmentally acceptable than diesels. Microturbines can be a good choice for small applications (less than $100 \mathrm{~kW}$ ); combustion turbines can be good for larger applications, where natural gas is available and emissions are a concern. UPS systems are well suited to applications where outages last less than about 15 minutes. Batteries can handle applications of a few $\mathrm{kW}$ for outages of about 1 to 2 hours. Hybrid technologies, which combine generation and storage technologies for specific applications, have many benefits and may be best if you need fuel redundancy, expect a wide range in duration of outages, or have multiple applications.

Low-Cost Energy. If low-cost fuel is available, or electric rates are high in your area, or both, you may be able to reduce your utility bill by generating some or all of your own power. Diesel, dual-fuel, and natural gas engines are the least expensive to purchase, but emissions and maintenance costs should be considered when the number of operating hours is high. Combustion turbines are preferred for large applications; they have lower maintenance costs and much lower emissions than reciprocating engines. Microturbines, which are relatively lower in efficiency and have higher capital costs, are probably not as cost-effective. Photovoltaics, although high in cost initially, often make sense in the long term, especially if the 
local utility has established net metering rules (see below for more information). Wind turbines are less expensive than PV arrays, but may not qualify for net metering. However, in areas with high average wind speeds, turbines can provide a substantial amount of energy. Hybrid systems - such as PV or wind with batteries-are more expensive but work over a broader range of fuel costs and applications than single technologies. In addition, using the waste heat generated by some DER technologies to produce both heat and power on site can reduce overall energy costs.

Stand-Alone Systems. A DER in this application will run around the clock and constantly match its output to the demand. Therefore, high efficiency is required to minimize fuel costs and emissions. Maintenance costs are also an important factor, and reliability is paramount. Engines and combustion turbines are often the first choices in terms of capital cost. Engines and microturbines are usually preferable for smaller applications; combustion turbines are preferable for larger applications. Fuel cells are the most expensive to install but desirable from an environmental perspective. $P V$, wind turbines, and hybrid systems are beneficial in areas without adequate supplies of fossil fuels or where environmental permitting is difficult, and in off-grid applications where grid extensions are very expensive. Particularly in remote, off-grid areas, the cost of operating and maintaining fossil-fuel-fired engine gensets is significant. The cost of transporting and storing fuel, combined with the potential for fuel spills and subsequent cleanup, can make hybrid renewable energy systems much more life-cycle cost-effective than fossil gensets alone.

Combined Heat and Power (CHP). Only the powergeneration technologies that produce excess heat can be used for CHP applications; these include engines, combustion turbines, fuel cells, and microturbines. Additional equipment must be installed to capture the heat and use it in the secondary process, at an average additional cost of $\$ 400 / \mathrm{kW}$. Engines and turbines (including some microturbines) have been used for CHP applications. Any DER technology that can produce waste heat can be used in a CHP application with greater overall system efficiencies (because of the higher fuel utilization efficiency) and perhaps better economics. (See page 9 for more information. You can also use the CHP Online Calculator-see Resources on p. 16 - to determine whether CHP is costeffective for your needs.)

Peak Shaving. DER systems can generate power during the times when purchasing energy from the utility would be very expensive. These include peak demand hours, when time-of-use rates are in effect, and hours when utilities are capacity-constrained. Utilities often assess demand charges - monthly charges based on highest peak usage-for commercial customers. Using DER to limit peak usage will help you avoid these costs. The system may run 200 to 2000 hours per year, so you should consider the trade-off between installation costs and efficiency to select an appropriate DER technology. Engines and hybrids are likely to be preferable for small applications at lower run times, and turbines for larger applications at higher run times. PV systems can provide peak shaving in facilities where the greatest requirement for energy occurs when the solar resource is at its highest intensity, such as for air-conditioning in commercial buildings. For these applications, PV systems have excellent load-matching characteristics.

Power Quality. Any DER prime mover technology can be used to provide dedicated, high-quality power to highly sensitive or mission-critical loads and to eliminate downtime. For small applications and brief power outages, a UPS is likely to be the most economical choice. For voltage sags, spikes, noise, and other random $P Q$ anomalies, preferred technologies include batteries, flywheels, and SMES. They can be operated in a constantly-on mode, filtering out unwanted qualities of the power signal. Adding higher quality electronics and energy storage systems can improve the power quality of any prime mover technology. See page 8 for more information about power quality.

\section{Net Metering}

Net metering measures the difference between the electricity you buy from your utility and the electricity you produce using your own generating equipment. Your electric meter keeps track of this "net" difference as you generate electricity and take electricity from the grid. Your utility or electric service provider bills you for the "net" energy you use (if any) on a monthly or yearly basis, depending on the program. Net metering allows you to get full retail value for most, if not all, of the electricity you produce. Any excess electricity you generate goes back into the electric grid and essentially credits future energy use. Getting this high retail value for your excess electricity makes owning your own generating system more cost-effective. Net metering programs have been enacted in 35 states. Although specific requirements vary significantly from state to state, many programs allow net metering for residential and commercial customers, with system size limits of 10-100 kW. Check with your state's public utility commission for the specific rules that could apply to you.

For a summary of state net metering programs, see www.eren.doe.gov/greenpower/netmetering. 
Table 2. Summary of Cost and Performance Parameters for Distributed Generation Technologies

\begin{tabular}{|c|c|c|c|c|c|c|c|}
\hline \multirow[t]{2}{*}{ Technology } & \multirow[t]{2}{*}{$\begin{array}{l}\text { Size Range } \\
\text { (kW) }\end{array}$} & \multirow{2}{*}{$\begin{array}{l}\text { Installed Cost } \\
\text { (\$/kW) } \\
\text { (2) }\end{array}$} & \multirow[t]{2}{*}{$\begin{array}{l}\text { Heat Rate } \\
\left(B t u / k W h_{e}\right)\end{array}$} & \multirow{2}{*}{$\begin{array}{l}\text { Approx. } \\
\text { Efficiency } \\
(\%)\end{array}$} & \multirow{2}{*}{$\begin{array}{l}\text { Variable } \\
\text { O\&M } \\
(\$ / k W h)\end{array}$} & \multicolumn{2}{|c|}{$\begin{array}{c}\text { Emissions (1) } \\
(\mathrm{lb} / \mathrm{kWh})\end{array}$} \\
\hline & & & & & & $\mathrm{NO}_{\mathrm{x}}$ & $\mathrm{CO}_{2}$ \\
\hline Diesel Engine & $1-10,000$ & $350-800$ & 7,800 & 45 & 0.025 & 0.017 & 1.7 \\
\hline Natural Gas Engine & $1-5,000$ & $450-1,100$ & 9,700 & 35 & 0.025 & 0.0059 & 0.97 \\
\hline Natural Gas Engine w/CHP (3) & $1-5,000$ & $575-1,225$ & 9,700 & 35 & 0.027 & 0.0059 & 0.97 \\
\hline Dual-Fuel Engine & $1-10,000$ & $625-1,000$ & 9,200 & 37 & 0.023 & 0.01 & 1.2 \\
\hline Microturbine & $15-60$ & $950-1,700$ & 12,200 & 28 & 0.014 & 0.00049 & 1.19 \\
\hline Microturbine w/CHP (3) & $15-60$ & $1,100-1,850$ & 12,200 & 28 & 0.014 & 0.00049 & 1.19 \\
\hline Combustion Turbine & $300-10,000$ & $550-1,700$ & 11,000 & 31 & 0.024 & 0.0012 & 1.15 \\
\hline Combustion Turbine w/CHP (3) & $300-10,000$ & $700-2,100$ & 11,000 & 31 & 0.024 & 0.0012 & 1.15 \\
\hline Fuel Cell & $100-250$ & $5,500+$ & 6,850 & 50 & $0.01-0.05$ & 0.000015 & 0.85 \\
\hline Photovoltaics & $0.01-8$ & $8,000-13,000$ & -- & $\mathrm{N} / \mathrm{A}$ & 0.002 & 0.0 & 0.0 \\
\hline Wind Turbine & $0.2-5,000$ & $1,000-3,000$ & -- & $\mathrm{N} / \mathrm{A}$ & 0.010 & 0.0 & 0.0 \\
\hline Battery & $1-1,000$ & $1,100-1,300$ & -- & 70 & 0.010 & $(4)$ & (4) \\
\hline Flywheel & $2-1,600$ & 400 & -- & 70 & 0.004 & (4) & (4) \\
\hline SMES & $750-5,000$ & 600 & -- & 70 & 0.020 & (4) & (4) \\
\hline Hybrid Systems & $1-10,000$ & (6) & (5) & (5) & (5) & (5) & (5) \\
\hline
\end{tabular}

(1) Nationwide utility averages for emissions from generating plants are $0.0035 \mathrm{lb} / \mathrm{kWh}$ of $\mathrm{NO}_{\mathrm{x}}$ and $1.32 \mathrm{lb} / \mathrm{kWh}$ of $\mathrm{CO}_{2}$.

(2) The high end of the range indicates costs with $\mathrm{NO}_{x}$ controls for the most severe emissions limits (internal combustion technologies only).

(3) Although the electric conversion efficiency of the prime mover does not change, CHP significantly improves the fuel utilization efficiency of a DER system.

(4) Storage devices have virtually no emissions at the point of use. However, the emissions associated with the production of the stored energy will be those from the generation source.

(5) Same as generation technology selected.

(6) Add cost of component technologies.

easily be fitted with pollution controls to run even cleaner. They are available in sizes ranging from about $300 \mathrm{~kW}$ to several hundred megawatts, and costs range from $\$ 910 / \mathrm{kW}$ to $\$ 1,400 / \mathrm{kW}$, installed.

- Microturbines are smaller, somewhat less efficient versions of combustion turbines, in the range of about 30 to $250 \mathrm{~kW}$. They run on natural gas at high speeds (typically around 90,000 rpm). The electrical output of the generator is typically passed through an inverter (an electronicsbased power converter, also called a power conditioning unit or PCU) to provide $60 \mathrm{~Hz}$ AC power. Microturbines targeted to the small industrial and commercial market are designed to be compact, affordable, reliable, modular and simple to install. The newest versions meet very low emissions requirements. Microturbines are commercially available and currently cost around $\$ 1,000 / \mathrm{kW}$.

- Fuel Cells produce DC electricity by a thermochemical process in which hydrogen $\left(\mathrm{H}_{2}\right)$ is passed over an anode and air over a cathode in an electrolyte bath; the DC power is inverted to $\mathrm{AC}$ for grid operation. Byproducts are heat, water, and carbon dioxide, making fuel cells one of the cleanest sources of energy. Unless it is transported to the site, the hydrogen comes from reforming a fuel such as natural gas or propane, a process that may produce environmental emissions. Fuel cells using a phosphoric acid electrolyte were the first to become commercially available; solid

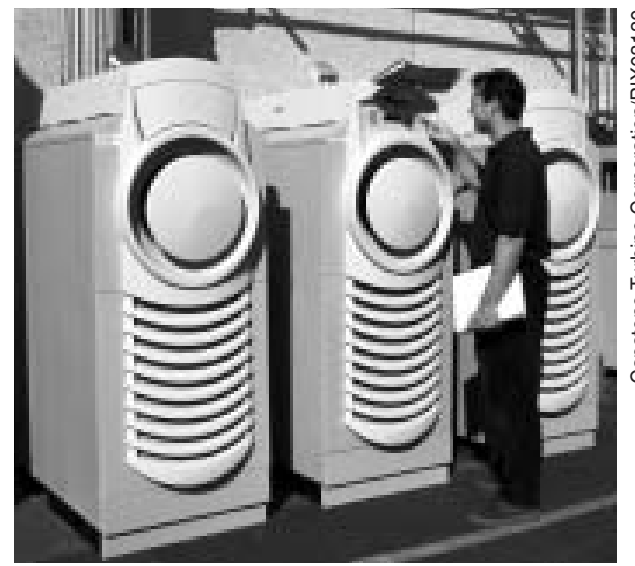

Microturbines can be powered by natural gas or biofuels to provide a reliable source of power.

oxide, molten carbonate, and proton exchange membrane (PEM) technologies are poised to follow. Fuel cells are efficient, quiet, and modular. 
They are available in sizes ranging from a few watts to $200 \mathrm{~kW}$ - the current commercially available size for stationary power applications. Although costs are expected to go down, fuel cells are now one of the most expensive DER technologies, starting at about $\$ 5,500 / \mathrm{kW}$, installed. FEMP's Federal Technology Alert on fuel cells (see Resources, p. 16) provides more information.

- Photovoltaic Cells are thin layers of a semiconductor (usually crystalline silicon) that convert sunlight directly to DC electricity; an inverter converts the DC to standard AC power for connection to utility systems. These "solar cells" are built up into panels with power ratings ranging from a few watts to about $100 \mathrm{~W}$. The panels are modular and can be configured into larger arrays to match almost any load requirement. Noise and emissions are nonexistent, and maintenance is minimal because there are no moving parts. Photovoltaic systems are a proven technology and are available from numerous manufacturers. Depending on the application, $\mathrm{PV}$ systems can range from $\$ 8,000 / \mathrm{kW}$ to $\$ 13,000 / \mathrm{kW}$, installed. Grid-connected systems typically fall in the low end of the range, while systems with battery storage constitute the high end.

- Wind Turbines, another renewable energy technology, contain propellerlike blades that turn the energy in the wind into rotational motion to drive a generator. Most wind turbines are asynchronous, meaning they turn at variable speeds; the output of the generator must pass through an inverter to achieve $60 \mathrm{~Hz}$ AC electricity. Wind turbines range in electrical output from a few watts to more than $1 \mathrm{MW}$. Applications include remote power systems, small-scale or residential electricity production, and utility-scale power generation. DERscale systems can cost anywhere from $\$ 1,000 / \mathrm{kW}$ to $\$ 3,000 / \mathrm{kW}$ installed, depending on the application. Like photovoltaics, wind turbines are a

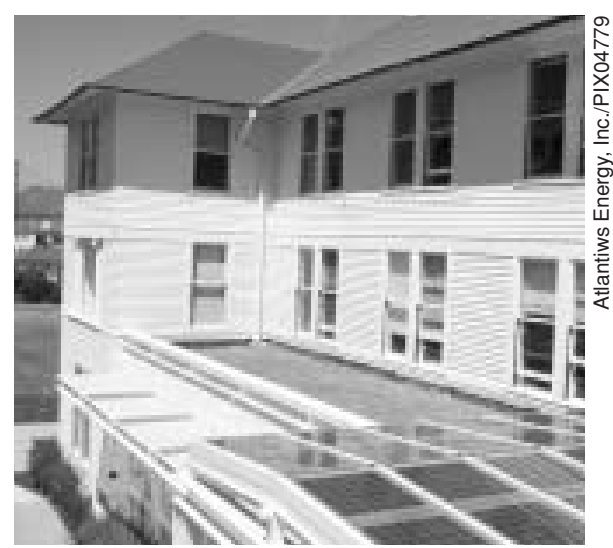

A photovoltaic system over the entryway to this building in San Francisco generates power on site.

proven technology and are available from several manufacturers.

- Storage Devices take energy from the electric grid or another source (such as a renewable DER) and store it, making it available when needed. Storage technologies currently available have a range of characteristics for various applications. Batteries are the most common form of electric energy storage; applications range from low-power uses, such as remote telecommunications, to high-power uses, such as utility grid support (requiring an inverter). A UPS is another common storage system, typically consisting of batteries mated to control electronics that convert stored energy to AC electricity and dispatch it as needed (for example, to provide full power during an outage or to smooth out power quality problems). Flywheels convert electric or mechanical energy into rotational energy and invert it for use when needed.

Superconducting magnetic energy storage (SMES) uses a magnetic coil cooled to very low temperatures to store electric energy with little loss; like other DC devices, it uses an inverter to convert $\mathrm{DC}$ to $\mathrm{AC}$ that can be dispatched to a utility grid. These storage technologies are all commercially available and becoming more cost-effective as applications increase. The cost of purchasing and installing energy storage systems can range from $\$ 1,100 / \mathrm{kW}$ to $\$ 1,300 / \mathrm{kW}$.
- Hybrid Systems are combinations of these technologies, designed for specific or unusual applications. Renewable energy technologies such as wind and solar systems, for example, depend on energy sources that cannot be dispatched-i.e., we have no control over their availability. For this reason, it can be necessary to combine them in a hybrid system, such as a PV system with battery backup, to collect energy for use when a facility needs it. Nonrenewable hybrid DER systems are also used; one example is a battery system packaged with a microturbine, to ride through short outages with the batteries and use backup power from the microturbine for sustained outages.

Depending on your needs, more than one of these technologies and systems might work for you. In that case, you could custom-design several technologies and control systems to obtain the greatest benefit.

\section{What are the environmental issues?}

An important consideration in choosing a DER technology is the environmental impact associated with it. Certain DER systems can have a positive impact on air emissions, particularly $\mathrm{NO}_{\mathrm{x}}$ and $\mathrm{SO}_{\mathrm{x}}$ which are by-products of fossil fuel combustion and key constituents of smog. Table 2 shows output levels of the key

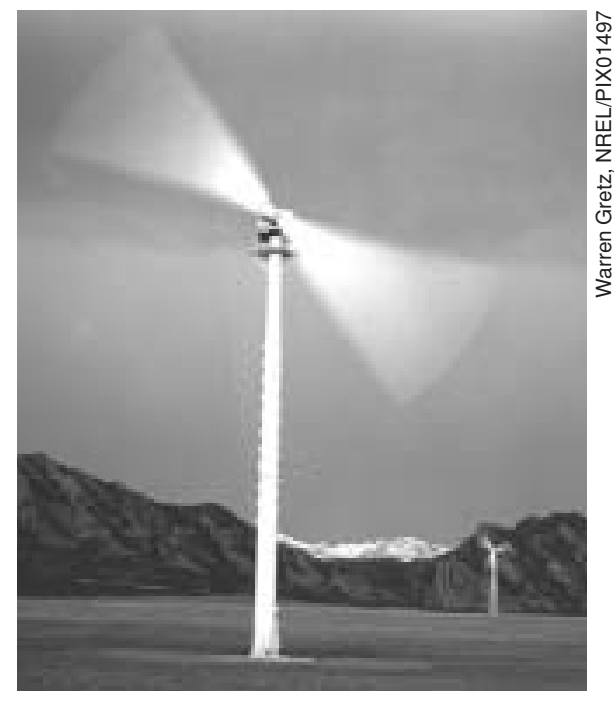

Wind turbines can be purchased in either small or large sizes, depending on a facility's needs. 


\section{Power Quality}

The power generated by an electric utility starts out as a "clean" $60 \mathrm{~Hz}$ sine wave (Fig. 1), but both utility and customer equipment can affect the pureness (quality) of the power delivered to the user. Load and generation changes, equipment switching, and electronically controlled loads can all cause significant disturbances to the electrical waveform. Poor power quality can be merely annoying or it can adversely affect or damage sensitive loads such as computers, adjustable-speed drives, and motors, disrupting important facility processes.

Symptoms of poor PQ include the following:

Voltage sags and swells - the voltage is too high or too low for a period of several cycles to several minutes (Fig.2).

Voltage spikes - sharp, randomly occurring pulses in the voltage (Fig. 3).

Momentary outage - complete interruption of power for up to 5 minutes (Fig. 4).

Harmonic distortion - variation from a pure sine wave due to harmonic frequencies (Fig. 5).

Other signs of poor $\mathrm{PQ}$ are variations in the frequency from a constant $60 \mathrm{~Hz}$, noise (low-level random voltage variations), and unbalanced voltages and currents between the three phases of the electric system.

How do you know if you've got PQ problems? You may see lights flicker or go dim or bright. Motors can vibrate, make noise, overheat, or stall. Outages are easy: everything goes black. Some symptoms are hard to detect, so you might want to ask your local utility or a consultant to monitor your power and do a $P Q$ analysis for you.

If your facility has experienced any of these symptoms, first ask your local utility or vendors about the solutions they could provide. In many cases, improper grounding or problems inside your facility may be to blame; sometimes nearby customers are the source of the problem. Because many utilities make no warranties concerning power quality, you may need to consider installing PQ mitigation technologies. These include UPS, battery systems, storage technologies, motor-generator sets, isolation transformers, voltage regulators, line conditioners, filters, shielding and grounding techniques, and surge suppressors.
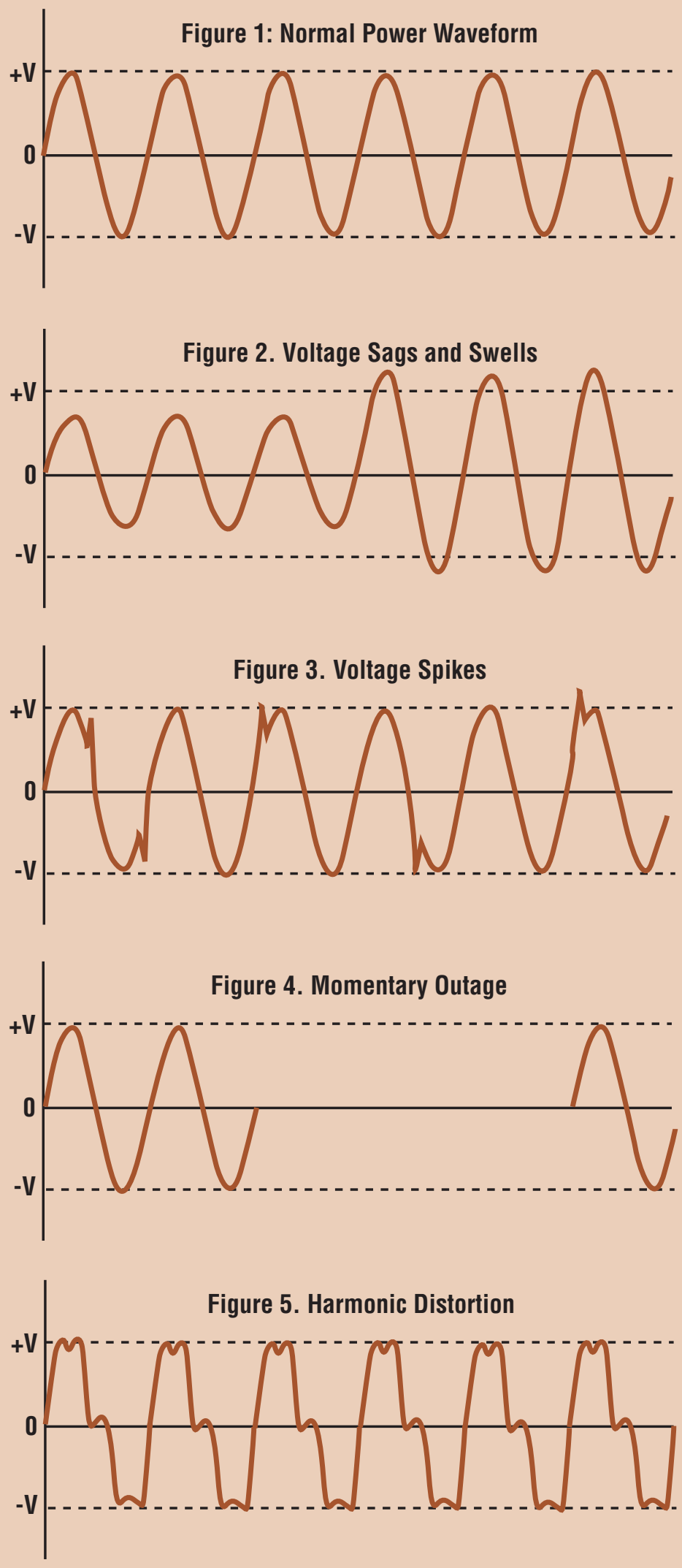


\section{Combined Heat and Power}

Many types of distributed generation can provide useful and valuable thermal energy by capturing excess heat energy produced during electricity generation and using it to heat or cool water or interior space. The excess heat can also be used as energy input to an industrial process, in lieu of burning fuel. This energy capture and reuse process is known as combined heat and power, CHP, or cogeneration.

Some energy users require substantial amounts of heat, especially for industrial, institutional and agricultural operations. In those cases, CHP can save enough on fuel costs to substantially improve the overall economics of DER installations.

Federal facilities that are likely to benefit the most from CHP applications include hospitals, prisons, R\&D facilities, and industrial buildings.

Assuming that the combustion of fuel to produce heat (usually in a boiler) is typically up to $85 \%$ efficient, each Btu of heat captured from the distributed generator in a CHP process offsets the need to burn about 1.18 Btu of fuel. The incremental project cost for CHP is highly site-specific, but generally about $\$ 400 / \mathrm{kW}$. This represents the estimated costs for piping, heat exchangers, and engineering associated with installing CHP. CHP system integration can sometimes be simplified at facilities that already have a central plant or a large mechanical room, thereby reducing costs. And any site with a steam plant that runs at moderate to high pressures might be able to use backpressure steam turbines to generate electricity cost-effectively.

$\mathrm{CHP}$ can also have substantial environmental benefits by reducing air emissions from boilers or other processes that require heat input. This fact may be helpful in obtaining permits from local air regulatory authorities. Nominal values for avoidable boiler emissions are shown in the table below. They are based on the leading data source for this kind of information, the U.S. Environmental Protection Agency. In addition to nitrogen oxides and carbon dioxide $\left(\mathrm{NO}_{\mathrm{X}}\right.$ and $\left.\mathrm{CO}_{2}\right)$, boiler emissions can also include sulfur oxides $\left(\mathrm{SO}_{\mathrm{X}}\right.$ ), carbon monoxide (CO), volatile organic compounds (VOCs) and particulate matter (PM). (Values shown in Table 3 are representative of boilers currently in use that are the most likely candidates for replacement by CHP, so they are somewhat higher than values for newer, more efficient boilers.)

\section{Table 3. Avoided Boiler Air Emissions for CHP Operation (pounds per million Btu)}

\begin{tabular}{lcccccc}
\hline & $\mathrm{NO}_{\mathrm{x}}$ & $\mathrm{SO}_{\mathrm{x}}$ & $\mathrm{CO}$ & $\mathrm{CO}_{2}$ & $\mathrm{VOC}$ & $\mathrm{PM}$ \\
\hline Nominal & 0.14706 & 0.00059 & 0.0824 & 118 & 0.00539 & 0.00745 \\
\hline Best Reported & 0.03137 & & 0.0235 & & & \\
\hline Poorest Reported & 0.2745 & & 0.0961 & & & \\
\hline
\end{tabular}

FEMP offers free CHP screenings; please contact your DOE Regional Office representative for more information (see Resources on p. 16). And see Oak Ridge National Laboratory's online CHP evaluator: www.eren.doe.gov/ der/chp/chp-eval.html. regulated emissions of DER technologies, $\mathrm{CO}_{2}$ and $\mathrm{NO}_{x} ; \mathrm{SO}_{\mathrm{x}}$ emissions are negligible for most DER technologies, since the fuel used is typically natural gas. Note that the units employed are pounds per kilowatt-hour $(\mathrm{lb} / \mathrm{kWh})$; this is an example of an output-based standard, which relates emissions levels to the efficiency of the technology, and allows technologies to be compared on a consistent basis. Sometimes emissions measurements are given in terms of input (e.g., pounds of pollutant per million Btu of fuel input) or on the basis of concentration (parts per million, or $\mathrm{ppm}$ ). These measures do not clearly link actual emissions to the amount of product (in this case, $\mathrm{kWh}$ of energy), making it difficult to determine which technologies are the cleanest.

Table 2 lists the heat rates of the technologies in terms of Btu $/ \mathrm{kWh}$, representing the amount of fuel input required per kilowatt-hour of electrical output produced. This can help you evaluate the fuel requirements of a DER for a given output and hours of operation, as well as output-based emissions in $\mathrm{lb} / \mathrm{kWh}$, so you can choose the cleanest feasible technology for your facility. Note that renewable energy systems and fuel cells have virtually no air emissions. Because overall system efficiencies are higher, $\mathrm{CHP}$ systems also have lower emissions than DER systems that do not utilize waste heat.

Keep in mind that any energy your facility generates usually displaces energy previously generated by some other source, so net emissions are a key consideration. For example, if you install a wind turbine, all the air emissions from the usual generation source (e.g., the local utility), will be avoided for each $\mathrm{kWh}$ of energy the wind turbine produces. On the other hand, if you install a diesel engine, then it is possible that net emissions will be greater, because diesels have higher levels of some key emissions on a per-unit basis than most conventional utility generation methods. Table 2 shows the average emissions for U.S. utility generation, which is a mix of fossil fuel (coal, oil, and natural gas), 


\section{Electrical Output: AC vs. DC}

Virtually all electric systems in common use in North America today are $60 \mathrm{~Hz}$ alternating current (AC) systems. Some DER technologies-like engines and combustion turbines-produce AC power directly and can be connected to the electric grid or AC loads in a straightforward manner. Other technologies-like fuel cells, photovoltaics, and wind turbines-produce direct current (DC) power, which must be passed through a power electronics device, called an inverter or power-conditioning unit, to produce $60 \mathrm{~Hz}$ output that can then be connected to AC systems.

hydropower, nuclear, geothermal, and a few other sources.

Noise will also be a consideration in choosing a DER technology, because of the proximity of the system to homes and businesses. Most urban and suburban areas have noise ordinances, so mufflers or other sound attenuation methods may be necessary. In addition, visual and aesthetic impacts are sometimes a concern, requiring landscaping, enclosures, or other measures.

\section{What fuels should be used?}

Availability, price, and storage are the key concerns regarding the fuel used to power your DER system.

Diesel fuel is readily available at a reasonable cost; however, it requires an on-site storage tank and periodic deliveries, and spills or fumes are always possible.

Biodiesel fuel can be an alternative for diesel engine generator sets in areas where it's available. Biodiesel is made by reacting natural oils and fats with an alcohol. It is generally distributed as a $20 \%$ blend with number 1 or 2 diesel fuel. Biodiesel can significantly reduce $\mathrm{CO}_{2}, \mathrm{SO}_{2}$, and particulate matter emissions, but it may increase $\mathrm{NO}_{\mathrm{x}}$ in some cases.
Natural gas is a cleaner alternative to diesel, and it is comparable in terms of overall cost. In areas where gas utilities have pipelines, a gas line extension may be required, at additional cost, but a storage tank is not needed. If it is impractical or prohibitively expensive to run a gas line, you may need gas delivery and a storage tank. Propane is another alternative to diesel fuel, where natural gas is not available. Natural gas and propane may or may not be cleaner alternatives to biodiesel; it depends on the application.

Biomass-plant matter such as trees, grasses, agricultural crops or other biological material — can also be used in place of some fossil fuels. The most common forms of biomass used to generate electricity are the residues from the food, fiber, and forest product industries. But municipal solid waste facilities and sewage treatment plants can also produce fuel to power DER technologies.

PV systems depend on the availability of sufficient sunlight in a given area. By paying careful attention to the design and placement of the solar panels, and adding energy storage batteries (typically, the deep discharge type), you can maximize the potential of your solar installation.

Wind energy is also highly dependent on location, especially on the average wind speed in a given locale and the daily and seasonal variations in wind speed. Again, adding storage can pay off in terms of the overall functionality of a wind system.

Hybrid systems, such as wind or PV plus storage and a small diesel backup generator, may be necessary and costeffective in situations where high reliability and / or stand-alone operations are required.

\section{STEP 3: Screen the Technologies}

At this point, it is a good idea to perform a screening exercise to eliminate DER candidates that are not really practical or feasible for your facility. This helps you make sure that there are no "showstoppers" to derail your project, and that the economics of your choices are favorable.

For example, if natural gas is not available at your facility, a technology that requires it is clearly not the right choice. If air emissions are strictly controlled in your area, diesel engines would not be acceptable, either, and other fossil fuel technologies may be problematic, as well. Be sure your choices do not stop the show in terms of making your project a success.

You can also look at the barriers in Step 6 to see if any of them would categorically rule out any of the DER options you have selected. Then, you'll want to conduct an economic evaluation.

Some people balk at the high first costs of certain DER technologies, such as fuel cells and PV systems. Researchers are still working on ways to reduce these initial costs to more competitive levels. However, many DER technologies are life-cycle cost-effective in certain applications right now.

Federal facilities are required to perform life-cycle cost assessments on all planned energy projects, because these assessments take into account the benefits of a project over its entire operational life. For example, a PV system has a higher capital cost than a similarly sized natural gas engine. But the PV system does not use fuel and can last up to 20 years or more. The natural gas engine, in contrast, will use a lot of fuel during its lifetime, which may only be a few years.

You can evaluate the cost-effectiveness of a DER system by comparing the lifecycle costs of your current energy usage scenario to the scenario in which a DER system is designed, installed, and operated.

To simplify this process, DOE provides a Building Life Cycle Cost (BLCC) economic analysis software tool, which is used to analyze the life-cycle costeffectiveness of energy technologies (including DER) in an integrated facility environment. See Resources on p. 16 for more information on BLCC and how to use it. 


\section{F E D E R L E NER G Y MANAGEMENT PROG RA M}

\section{STEP 4: Acquire Resources}

Line up resources you can call on for assistance- the earlier, the better. These can include-

- Process experts. Contact your DOE Regional Office (see FEMP's Web site for a list of contacts). Your Regional Office representative can walk you through the process and help you work with regulatory agencies, utilities, energy service providers (ESPs), energy service companies (ESCOs), national laboratories, and independent consultants in your area.

- Technical experts. Programs at DOE, FEMP, and the national laboratories are staffed by many technical experts in DER. Your DOE Regional Office representative can help you identify the people to contact for assistance. You might also want to contact local utilities, your state's energy office, ESPs, ESCOs, consultants, manufacturers, and equipment vendors yourself.

- Financial support. In addition to direct appropriations, there are two approaches that Federal agencies can take to share the financial risk of a project. They are utility energy services contracting (UESC) and FEMP's energy savings performance contracting (ESPC and Super ESPC) programs. These contracts allow Federal agencies to leverage privatesector financing to install energy improvements when appropriated funds are not available. The utility or ESCO is repaid for capital costs from the savings in the agency's utility bill. Participating local utilities and ESCOs can contract for installation. Look for local utility rebates, tax credits, state or Federal incentive programs, and opportunities to partner with privatesector financers, developers, and manufacturers as well; check the FEMP Web site for more information about SER funding opportunities.

- FEMP DER Program. FEMP offers a variety of services to Federal agencies that are considering DER projects, including technical assistance, alternative financing assistance, education, and outreach. See the FEMP Web site and check with your DOE Regional Office representative (see Resources on p. 16) for more information.

\section{STEP 5: Develop a Project Plan}

At this point, you should have a specific technology approach in mind, designed to meet your facility's energy needs. One of the first things you will need to do is evaluate the feasibility of your DER concept.

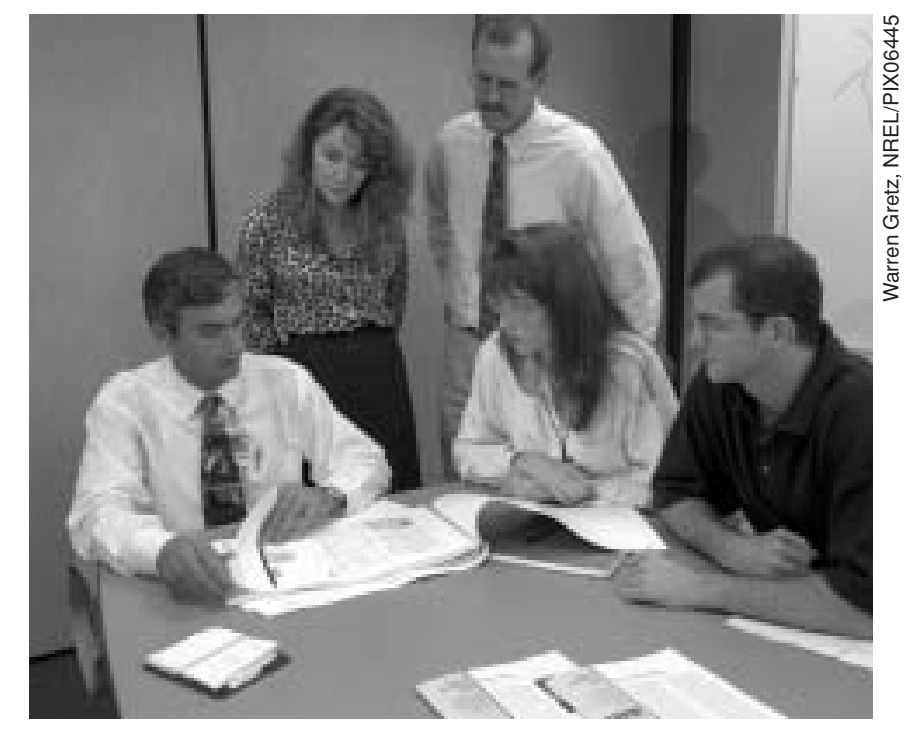

DOE FEMP can help your agency obtain innovative financing for DER projects.

permits are not required for PV systems.) These tasks should be done concurrently, since they are largely independent of each other. Note, however, that permits and utility connections can be costly; this could change the economic viability of a project that looked promising in the feasibility study.

- Financing. Explore financing options, using the resources described in Step 4, where possible. Contact your State Energy Office, DOE Regional Office representative, or local utility to see if any incentive programs are available to help with the cost of your DER system.

- Air Permits. Apply for air permits from the local air resources control board, as needed. Depending on the size, type, and potential impacts of your project, this can take up to six months for technologies having emissions. Fees will be assessed to evaluate the project, and will probably be proportional to the expected total yearly emissions. See Step 6 for additional information on air permits.

- Utility Connections and Rates. Apply for interconnections with local utilities. This includes electric interconnections for all DER projects connected to the utility, and gas line interconnections for projects 
requiring gas at higher volumes and pressures than the gas distribution system can provide. Typically, you will file an application with the utility, providing basic information about the proposed project and enclosing a nominal payment for processing and review. You will be informed after a specified period (typically, two to three weeks) whether a more involved study is required, what it will include, what it will cost, and approximately how long it will take (typically, about six weeks). This study will then describe the utility system upgrades (if any) that are necessary, what they will cost, and when they can be scheduled. It is then up to you to evaluate the cost in relation to your project's total cost and projected savings, and decide if your project is still cost-effective. See Step 6 for more information.

Utility rate impacts should also be investigated carefully. A new DER system can change your facility's energy demand and thus your rate structure. Large, gas-fired DER systems have high, consistent fuel demands, though you might be able to negotiate a lower fuel rate. Interruptible electric rates may provide cost savings if the DER system provides backup power. It is a good idea to look into anything that can save money and improve the economics of your DER system.

\section{STEP 6: Address Potential Barriers}

As your project nears completion, you will need to work with various entities to obtain permits, connect to the utility system, and perform other activities external to your facility. Some of these activities will require more time, effort, and money than you originally estimated and may pose certain barriers you will have to overcome. This section will help you identify potential project barriers; estimate their impacts on your project in terms of additional time, money, and expertise required; and for- mulate plans and strategies to overcome or avoid them.

\section{Overcoming technical barriers}

These barriers relate primarily to your local utility's electrical interconnection requirements, which are meant to ensure that your DER will not negatively impact the reliability, safety, and power quality of the electric grid system. Other technical barriers can include fuel availability or storage; space limitations; power quality impacts; fire, safety, and zoning requirements; and operations and maintenance issues.

You can begin by finding a contact person at the utility and asking for interconnection guidelines. Although the utility might not have established formal guidelines or rules, someone there should be responsible for handling interconnection requests.

Some utilities have expedited or simplified rules for certain types of DER. For example, renewable energy systems producing less than $10 \mathrm{~kW}$ may require nothing more than an inspection by the utility. Larger DER installations may require an engineering review, or even a full-fledged study. A study can take a utility from two to six weeks to perform, and you will probably be required to pay the utility's costs to conduct it. The result may be that protective equipment or other hardware must be installed, and you will be required to pay for that as well.

How can you tell if the utility's demands are appropriate for your specific installation? And how do you make sure that the process is handled with a minimum of delays? Here are some tips:

- Find someone to be your point of contact at the utility and maintain this throughout the process. A recent study, Making Connections: Case Studies of Interconnection Barriers and their Impact on Distributed Power
Projects (see Resources on p. 16), found that this was a consistent factor among projects that reported timely progress in obtaining interconnections.

- Ask the utility contact for proper application forms, and make sure you understand the technical data they are requesting. You or the contractor will have to provide these data when applying, and you may need to contact equipment vendors or other resources to obtain the data.

- Ask the utility to specify how long it will take to process the application, and what fees must be submitted with it.

- Utility commissions in some states have established regulations specifying the interconnection process. Find a contact person at your state's utility commission and ask for any guidelines or rules that apply. Also, ask whom to contact for dispute resolution, if that becomes necessary.

- Requirements for smaller DER systems should be easier, especially those for renewable energy systems. For installations under $10 \mathrm{~kW}$, requirements are often minimal to none, particularly for renewable energy systems. For systems up to $100 \mathrm{~kW}$, a study is likely to be 


\section{FE DERAL ENERG Y MANAGEMENT PROGRA M}

required, but it should not take more than a few hours for the utility engineer to determine impacts, and interconnection requirements should not be great. Above $100 \mathrm{~kW}$, the impacts on the utility system can be significant, so more study is likely to be needed, and interconnection costs are likely to be higher.

- If the DER will be used for on-site power requirements only, and no power will be exported or sold back to the utility, the interconnection requirements may be different from those for an exporting condition. For safety, utilities will require that the DER have protection equipment that will disconnect it if the utility system shuts down.

- If the utility has an interconnection handbook, as many do, it will specify the process and requirements, both for the utility and for the DER applicant. It should also specify time limits for various steps in the process, and what costs must be borne by the applicant.

- Some utilities have expedited rules for "certified" DER equipment, i.e., systems that have been tested and approved for use on the utility's distribution system.

- The Institute of Electrical and Electronics Engineers (IEEE) is developing a standard, labeled P1547, for interconnection of DER facilities; although it had not yet been approved by the date of this publication, many states are adopting similar rules. If your facility meets this proposed standard, this should expedite the process.

- If possible, find out what other facilities in your utility's service area have done or are considering in terms of DER projects. Other facility managers may be able to offer you valuable advice based on their own experiences.

If your DER project involves the use of natural gas or propane, don't forget to contact your local gas utility if it is not the same as your electric utility. Your gas utility may have additional or different requirements and procedures for implementing DER projects.

\section{Overcoming regulatory barriers}

Moving to the operational stage in a DER project means obtaining numerous permits and approvals. These can be economic as well as regulatory barriers, because time, effort, and money go into overcoming them. Since many permits require fixed fees regardless of the size of the DER project, the impacts on smaller projects can be greater than those for large projects. The Making Connections study documented numerous cases in which the economics of small projects were seriously impacted by the costs of meeting regulatory permitting, where such costs were a smaller percentage of larger projects.

Other barriers arise because of utility regulations. Standby charges are assessed because the utility is obligated to serve your load if the DER is not available, and the utility must maintain adequate distribution facilities. Exit fees repay the utility for distribution facilities already built that are "stranded" because your DER reduces the utility's return on investment. Similarly, regional transmission charges may be assessed for stranded transmission assets. Ask the utility what charges apply in your case.

Environmental permitting (primarily, obtaining an emissions permit) is probably the single most arduous and costly task in getting a DER online. Contact your state or local air quality management agency in charge of enforcing air regulations. Ask them the following:

- What are the air emission regulations in my area?

- How do I apply for an emissions permit?

-What data do I need to supply?

-What are the fees for the permit? Typically, fees are proportional to the expected amount of annual pollutants. Renewable systems and fuel cells should require minimal permitting, because they have virtually no emissions.
For most states, air permit requirements and the required forms are available on the Internet.

Note that even if the DER displaces an older, less efficient or more-polluting source, it may be treated as a "new source" and be subject to much more stringent emissions requirements. Some states make an allowance for the emissions reduced by using CHP (see page 9), which could make permitting requirements less stringent. However, most states do not make such an allowance, so be sure to ask the air regulatory agency whether $\mathrm{CHP}$ allowances are given in your state.

Land use or conditional use permits may be required by the local city or county government, and will depend on zoning regulations governing the site. Find a contact at the local planning department and ask your contact what permits are required, what the requisite fees are, and what the application process and schedule are. A public hearing might be required, which is also an excellent opportunity to make a positive presentation on your project to win local support.

It is often possible to require a contractor to obtain all the studies, permits, interconnection agreements, and other requirements as part of a turn-key design/ build/operate contract. You can explore options for such a contract when considering financing alternatives. Ask potential DER developers what options are available and appropriate for your site.

\section{STEP 7: Install and Operate Your DER!}

Now you are ready to build and operate your new DER system. Congratulations! You are adding an important new energy source to your facility that will bring many benefits to your operations and improve your bottom line. 


\section{DER Process Flowchart}

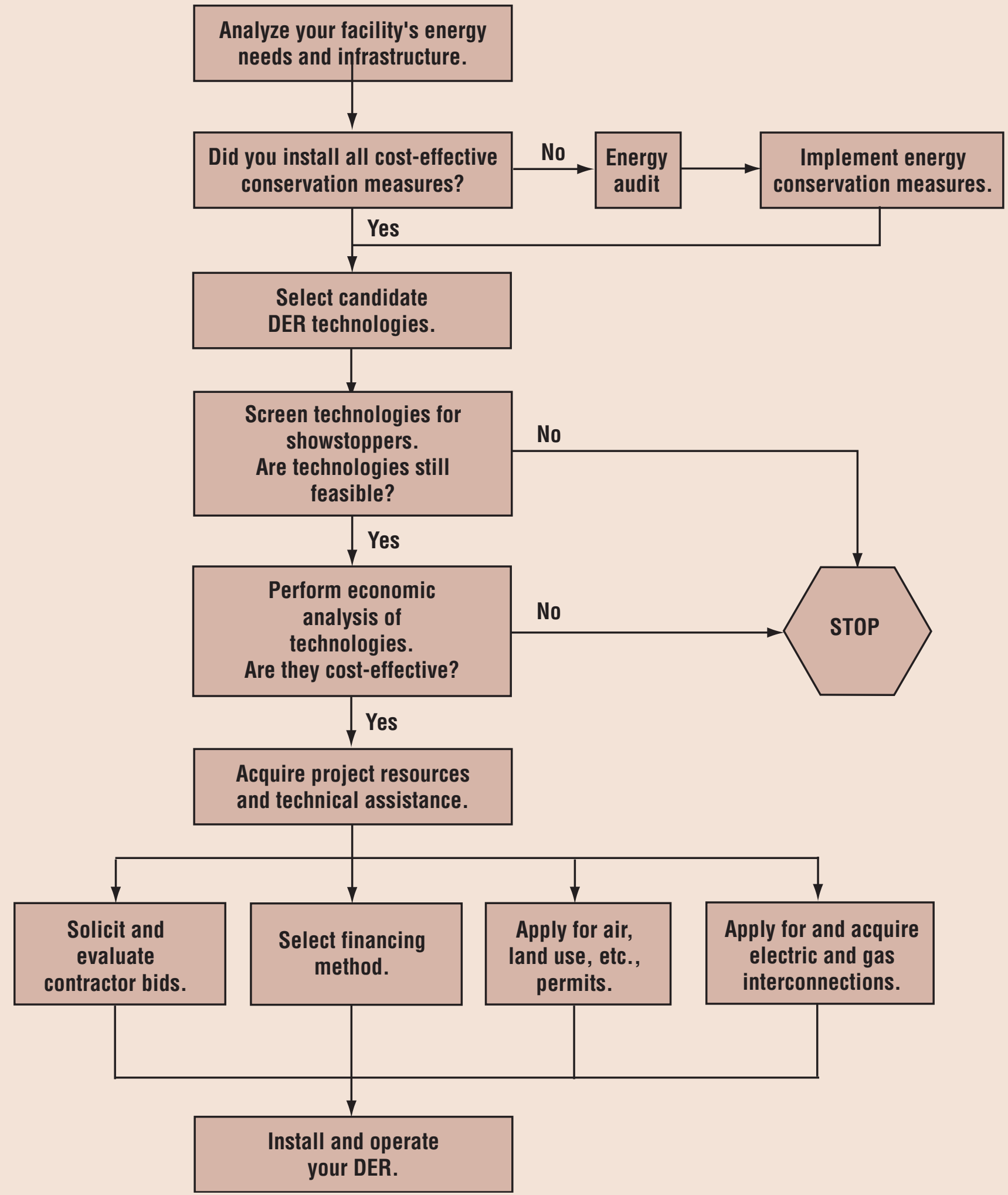




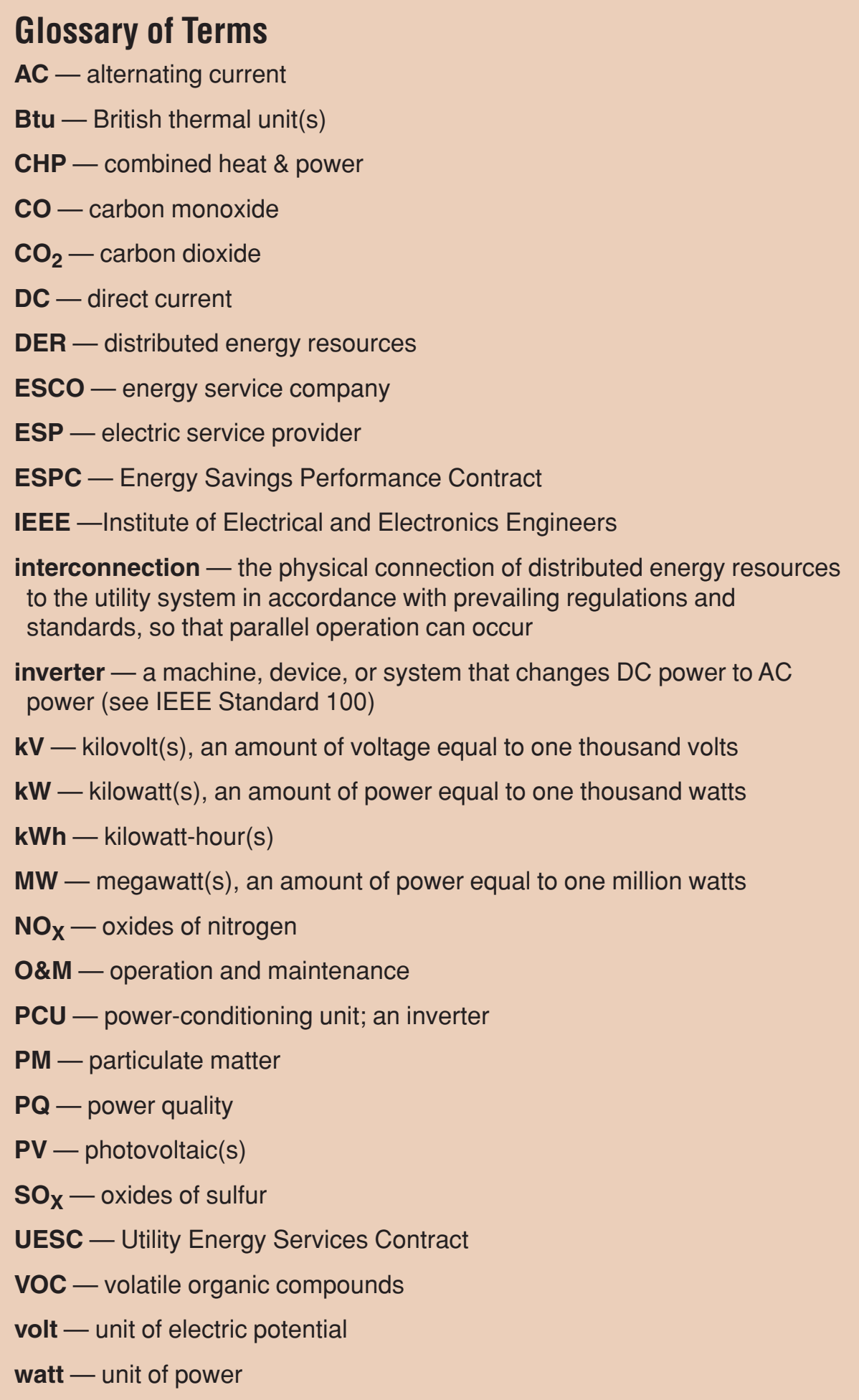




\section{Resources}

\section{Federal}

Department of Energy — Federal Energy

Management Program (FEMP)

www.eren.doe.gov/femp

Department of Energy — Distributed Energy

Resources Program

www.eren.doe.gov/der

Department of Energy — Regional Office FEMP

Representatives

www.eren.doe.gov/femp/aboutfemp/

fempcontacts.html.\#regional

Department of Energy — Office of Power

Technologies

www.eren.doe.gov/power

FEMP Design Assistance Program

www.eren.doe.gov/femp/techassist/

designassist.html

FEMP New Technology Demonstration Program

(NTDP)

www.eren.doe.gov/femp/prodtech/

newtechdemo.html

FEMP Federal Technology Alerts

www.eren.doe.gov/femp/prodtech/

fed_techalert.html

FEMP Renewable Energy Resources

www.eren.doe.gov/femp/techassist/

renewenergy.html

FEMP SAVEnergy Program

www.eren.doe.gov/femp/techassist/

savenergyprog.html

FEMP Software and Analytical Tools

www.eren.doe.gov/femp/techassist/

softwaretools/softwaretools.html

DOE Software and Analytical Tools

www.eren.doe.gov/buildings/tools_directory/

Federal Incentives for Commercial Solar

Applications

www.mdv-seia.org/federal_incentives.htm

Green Power Network — State Net Metering

Programs

www.eren.doe.gov/greenpower/netmetering/

index.shtml

Making Connections: Case Studies of

Interconnection Barriers and their Impact on

Distributed Power Projects

www.nrel.gov/docs/fy00osti/28053.pdf
Building Life-Cycle Cost (BLCC) Software Tool for

Download

www.eren.doe.gov/femp/techassist/

softwaretools/softwaretools.html

\section{Industry}

Edison Electric Institute

www.eei.org

Energy-efficient Product Information

www.energystar.gov

Engine and Turbine Manufacturers Directory

www.dieselpub.com/catalog/

United States Fuel Cell Council

www.usfcc.com

Online Fuel Cell Information Center

www.fuelcells.org

Fuel Cell Developers

http:/ /216.51.18.233/fcdevel.html

Solar Energy Industries Association

www.seia.org

Database of State Incentives for Renewable Energy www.dsireusa.org

American Wind Energy Association

www.awea.org

Electricity Storage Association

www.energystorage.org/

Distributed Power Coalition of America

www.distributedpower.com

National Association of Regulatory Utility

Commissioners

www.naruc.org

Institute of Electrical and Electronics Engineers www.ieee.org

Distributed Utility Associates, Livermore, California, contributed to the preparation of this guide.
For More Information

FEMP Help Desk

(800) 363-3732

International callers please

use (703) 287-8391

Web site: www.eren.doe.

gov/femp

General Contact

Shawn Herrera

Program Manager

Federal Energy

Management Program

U.S. Department of Energy

1000 Independence Ave., SW

Washington, D.C. 20585

Phone: (202) 586-1521

Fax: (202) 586-3000

shawn.herrera@ee.doe.gov

Laboratory Contacts

Distributed Energy

Resources:

Trina Brown

National Renewable

Energy Laboratory

1617 Cole Blvd.

Golden, CO 80401

Phone: (303) 384-7518

Fax: (303) 384-7411

trina_brown@nrel.gov

Combined Heat and

Power:

Patrick Hughes

Oak Ridge National

Laboratory

P.0. Box 2008, Bldg. 3147

Oak Ridge, TN 37831 -

6070

Phone: (865) 574-9337

Fax: (865) 574-9329

hughespj1@ornl.gov
Produced for the

U.S. Department

of Energy by the National

Renewable Energy

Laboratory,

a DOE national

laboratory

DOE/GO-102002-1520

May 2002 